\title{
Patrolling the White Man's Grave: The Impact of Disease on Anglo-American Naval Operations Against the Slave Trade, 1841-1862
}

\section{John C. Mitcham}

Les fonctions des marins britanniques et américains dans les escadrons antiesclavagistes les ont exposés aux dangers des maladies tropicales. Pendant toute la première moitié du dix-neuvième siècle, la malaria et la fièvre jaune ont ravagé les équipages européens et ont raccourci les patrouilles navales dans les régions littorales et riveraines de l'Afrique de l'ouest, exactement où les marchands d'esclaves pourraient le plus aisément être retrouvés et arrêtés. Par essai et erreur, les chefs navals britanniques et américains et les agents de la santé ont par la suite établi les politiques et les pratiques médicales qui ont atténué les effets les plus néfastes des maladies tropicales. Les opérations antiesclavagistes ont commencé à combattre, bien plus rigoureusement et à un coût bien modéré, les maladies débilitantes et la mort.

On 9 December 1844, Master's Mate John C. Lawrence of the USS Yorktown sighted the littoral of West Africa. Lawrence's diary preserves the sense of fear that gripped sailors upon reaching the coast: "At 1 p.m. through the lurid atmosphere on the larboard bow was discovered the continent of Africa - the land (when seen for the first time) fills the mind of a man of even only common information and reading with such a variety of interesting reflections from lofty to bad."1 Though based on popularized conceptions of Africa, Lawrence's concerns were well-grounded and foreshadowed his own fate. After patrolling the coast for several months, the Yorktown captured the American slaver Pons, transporting 903 slaves. Lawrence accompanied a prize crew that made for the port of Monrovia to liberate the Africans and take on fresh supplies. On New Years Day 1846, the Pons departed the Liberian coast for the United States, where the vessel would be delivered to American authorities for adjudication. Lawrence never took his share of the prize money, dying of "remittent fever" during the Atlantic crossing.

1 C. Herbert Gilliland, Voyage to a Thousand Cares: Master's Mate Lawrence with the African Squadron, 1844-1846 (Annapolis, 2004), 45.

The Northern Mariner/le marin du nord, XX No. 1, (January 2010), 37-56 
He was only twenty-four years old. ${ }^{2}$

Lawrence's fate was typical of many British and American sailors of the nineteenth century whose antislavery duties exposed them to the tropical diseases of Western Africa. Between 1825 and 1861, at least 1845 men from the Royal Navy's African Squadron died. ${ }^{3}$ The United States Navy, with far fewer personnel assigned to the African Station, lost eighty-six men. ${ }^{4}$ Tropical fevers were responsible for the vast majority of these deaths. Mosquitoes bearing malaria afflicted white sailors who lacked the natural resistance of native Africans. European visitors to the infamous Slave Coast died at a horrific rate that earned the region the sobriquet of "The White Man's Grave." Indeed, one noted historian estimates that half of all Europeans who arrived in West Africa were dead within one year. ${ }^{5}$

The dangers of tropical disease profoundly influenced British and American naval operations against the slave trade. Despite a primitive understanding of malaria and its origins, seasoned naval officers recognized that outbreaks of fever remained confined to coastal regions and employed measures aimed at limiting contact with the littoral. Strict orders prohibited sleeping ashore, while boat excursions into the interior were allowed only under extraordinary circumstances. Moreover, medical officers urged squadron leaders from both navies to abstain from using African ports, preferring distant St. Helena, Ascension, and the Cape Verde Islands. Not surprisingly, these limitations posed a dilemma for officers tasked with patrolling an extensive coastal region that afforded natural protection for shallow-draft slavers. Naval leaders recognized inshore blockades and coastal operations as the most effective means of interdicting slavers, and sought to establish a balance between service requirements and health concerns.

Ultimately, the fear of the "mysterious fevers" determined the navies' relationship with the littoral and riverine regions of West Africa. The American squadron adhered to strict guidelines and operated at a greater distance from the shoreline, with a negative effect on its operational efficiency. These policies placed a premium on the health of sailors, with one naval surgeon boasting "to contend against these adverse circumstances, and, in spite of them, to preserve the health and efficiency of the ships' companies, have, necessarily, ever been the dominant idea, the constant endeavor, in the administration of our squadrons on this station." The Royal Navy, by comparison, displayed far more tenacity in pursuing its offensive against the slave trade. Its early operations exposed thousands of sailors to the debilitating effects of fever, with disastrous results. By the mid-1840s, the British applied new principles that limited contact with

2 Gilliland, Voyage to a Thousand Cares, 291.

3 See Appendix B.

4 House Executive Document No. 73, 36 $6^{\text {th }}$ Congress, $1^{\text {st }}$ Session, 1-2. This official estimate only accounts for sailor mortality during the existence of an official American squadron, 1843-1861.

$5 \quad$ Philip D. Curtain, Disease and Empire: The Health of European Troops in the Conquest of Africa (New York, 1998), 1.

6 George Clymer, "Notices on the African Station," American Journal of the Medical Sciences XXXVIII (October 1859), 360. 
coastal regions and lowered sailor mortality. Later efforts to reengage the slave trade with coastal steamers and inshore blockades occurred only after the development of quinine and other medical remedies. These trends, as well as diminishing mortality rates, suggest that policy choices and operational deployments were driven by the dangers of the African disease. Between 1841 and 1862, British and American naval guidelines against the slave trade evolved in tandem with a maturing knowledge of tropical disease prevention.

From a wider perspective, the antislavery squadrons' experiences with malaria constitutes a useful case study of the West's ability to exert control over Africa. Transcending the confines of naval history and histories of the transatlantic slave trade, this approach positions the antislavery squadrons within the vibrant historiographical debate over the origins and causation of Western imperialism in Africa. ${ }^{7}$ Historians such

7 Most historical accounts of the British and American squadrons focus on matters of AngloAmerican relations, economic expansion, and the transatlantic slave trade. The seminal work for the Royal Navy's squadron is Christopher Lloyd, The Navy and the Slave Trade (London, 1968). Other books include William Ward, Royal Navy and the Slavers (New York, 1969) as well as more recent popular works such as Bernard Edwards, Royal Navy and the Slave Traders: Enforcing Abolition at Sea (Yorkshire, 2007) and Sian Rees, Sweet Water and Bitter: The Ships that Stopped the Slave Trade (London, 2009). The best account of the American squadron is Donald Canney, Africa Squadron: The U.S. Navy and the Slave Trade 1842-1861 (Washington, 2006). Older works dealing with the American squadron include: Alan R. Booth, "The United States African Squadron 1843-1861" in Jerry Butler, ed., Boston University Papers in African History(Boston, 1964); W.E.B. Dubois, Suppression of the African Slave-Trade (New York, 1965); James Pfautz, "The African Squadron of the United States Navy 1843-1861" (PhD dissertation, American University,1968); Judd Scott Harmon, "Marriage of Convenience: The United States Navy in Africa, 1820-1843," American Neptune XXXII, no. 4 (October 1972), 264-276; Earl McNeilly, "The United States Navy and the Suppression of the Slave Trade," (PhD dissertation, Case Western Reserve University 1973). For the American squadron's use as a tool of diplomacy and economic expansion, see John Schroeder, Shaping a Maritime Empire: The Commercial and Diplomatic Role of the American Navy, 1829-1861 (Connecticut, 1985), particularly 70-74. A more recent work, Mark Hunter's Policing the Sea: Anglo-American Relations and the Equatorial Atlantic, 1819-1865 (St. John's, 2008), provides an invaluable comparison of both squadrons.

A considerable volume of literature exists on the origins of British imperialism in West Africa. For general works on British imperialism, see: John Gallagher and Ronald Robinson, "The Imperialism of Free Trade," Economic History Review6, no.1 (1953), 1-15; and Africa and the Victorians: The Official Mind of Imperialism (London, 1961); D.K. Fieldhouse,“'Imperialism:' A Historiographical Revision,” Economic History Review 14, no.2 (1969), 187-209; P.J. Cain and A.G. Hopkins, British Imperialism: Innovation and Expansion, 1688-1914 (London, 1993). The introduction to Robin Winks, ed., The Oxford History of the British Empire Volume V: Historiography (Oxford, 1998) presents a helpful guide to these works. For more specific histories of imperialism in West Africa, see: John Gallagher, "Fowell Buxton and the New African Policy," Cambridge Historical Journal 10, no.1 (1950), 36-58; John Hargreaves, Prelude to the Partition of West Africa (London, 1963); Martin Lynn, "The 'Imperialism of Free Trade' and the Case of West Africa, 18301870," Journal of Imperial and Commonwealth History 15, no.1 (1986), 22-40; Commerce 
as Philip Curtin and Daniel Headrick have highlighted the inherent difficulties that tropical disease posed for Europeans in pursuit of imperial goals. ${ }^{8}$ In this environment, the vessels of the antislavery squadrons served as floating laboratories for epidemiology and disease prevention. Through experimentation and painfully acquired lessons, naval personnel developed effective measures that steadily diminished the threat posed by malaria and other tropical diseases. Their service patrolling the "White Man's Grave" provided Western powers with the institutional knowledge necessary to expand their influence in tropical regions, laying the groundwork for the later scramble for Africa of the 1880 s.

* $* *$

The littoral region of West Africa is an environment highly favorable for the prevalence of malaria. ${ }^{9}$ Countless rivers, marshes and swamps, and the tropical climate, make it a prime breeding ground for the female Anopheles mosquito that serves as the primary host for malaria parasites. ${ }^{10}$ The infected mosquitoes spread malaria by injecting parasitic forms into human beings. After a brief incubation period, the parasites enter the human blood stream, where they initiate a series of violent fevers every forty-eight hours. ${ }^{11}$ In Latin America and Southeast Asia, the most common strain of malaria is Plasmodium vivax. While victims infected with the vivax strain can expect a lifetime of relapses, they usually recover within a brief period of time. ${ }^{12}$ By contrast, the Plasmodium falciparum strain of sub-Saharan Africa presents a more significant danger to the human populace. In addition to severe fever attacks, falciparum causes anemia, brain damage, and often results in death, with the slight consolation that survivors acquire immunity against reinfection. In the nineteenth century, this immunity accounted for the perceived racial characteristics of malaria, as native Africans who survived infancy developed a childhood resistance to falciparum, while unacclimated adult whites faced the full fury of its ravages. ${ }^{13}$

and Economic Change in West Africa: The Palm Oil Trade in the Nineteenth Century (Cambridge, 1997).

8 See Philip Curtin,“"The White Man's Grave': Image and Reality, 1780-1850,” Journal of British Studies (November 1961), 94-110; The Image of Africa: British Ideas and Actions, 1780-1850 (Madison, 1964); Death by Migration: Europe's Encounter with the Tropical World in the Nineteenth Century (Cambridge, 1989); Disease and Empire: The Health of European Troops in the Conquest of Africa (1998); Michael Gelfand, Rivers of Death in Africa (Salisbury, 1967); Daniel Headrick, The Tools of Empire: Technology and European Imperialism in the Nineteenth Century (New York: 1981), particularly chapter 3: "Malaria, Quinine, and the Penetration of Africa," 58-79; Dennis Carlson, African Fever: A Study of Science, Technology, and Politics in West Africa, 1787-1864 (Canton, 1984). For an interesting comparison with French imperial experiences, see William Cohen, "Malaria and French Imperialism," Journal of African History 24, no. 1 (1983), 23-36.

9 For general histories of malaria, see: C.M. Poser and G.W. Bruyn, An Illustrated History of Malaria (New York, 1999); Randall M. Packard, The Making of a Tropical Disease: A Short History of Malaria (John Hopkins Press, 2007); James L.A. Webb Jr., Humanity's Burden: A Global History of Malaria (Cambridge, 2009). 
Western knowledge of malaria at the beginning of the nineteenth century was exceedingly limited. Medical professionals, in the era before the germ theory of disease, failed to associate mosquitoes with the transmission of fever. Most experts believed that some form of miasmic contagion caused the fevers. Indeed, the etymological origin of the word "malaria" is the medieval Italian mala aria, that is, "foul air."14 To defend against malarial infection, physicians urged the need to preserve the "constitution" of the body by avoiding physical exertion, sun exposure, alcohol, and sexual excesses. They also recommended protection from damp conditions and issued prohibitions against nighttime service ashore. ${ }^{15}$ Most importantly, they strongly advised keeping the ship and crew clear of the "poisonous airs" lurking on shore. This last precaution inadvertently saved many lives as the short range of the Anopheles mosquito ensured that sailors who remained sufficiently far enough from shore were safe from the coastal fevers.

The treatment of malaria was similarly undeveloped. Though Europeans recognized the healing powers of cinchona bark as far back as the seventeenth century, they lacked a sophisticated understanding of its application. Physicians mixed ground bark with varying amounts of wine as a cure for malaria patients rather than as a prophylactic to ward off potential infection. Most physicians also failed to distinguish between malaria and other forms of fever, and incorrectly prescribed cinchona bark for a vast array of ailments on which it had no effect. Moreover, medical professionals combined bark remedies with more traditional practices such as mercury healing and bloodletting. As a sign of lingering Galenic medical ideas, physicians and surgeons opened blood veins and applied purgative calomel treatments to restore the proper balance of fluids in the body. ${ }^{16}$ Given the anemic and dehydrated state of malaria victims, these practices likely killed more patients than they saved. The failure of cinchona bark to treat malarial fevers on a consistent basis raised significant doubts about its medicinal use. Indeed, popular disenchantment with bark remedies reached a climax in the early nineteenth century when many physicians abandoned the practice altogether. ${ }^{17}$ At a time when Western powers initiated a new phase of colonial expansion, the state of European medicine ensured that prolonged military service in West Africa was highly dangerous.

The Royal Navy confronted these conditions as it took the lead in interdicting the transatlantic slave trade. Following passage of the Slave Trade Act of 1807, the Admiralty dispatched a small squadron to West Africa with instructions to intercept

10 Webb, Humanity's Burden, 3.

11 Ibid., 4.

12 The Plasmodium vivax parasite can remain dormant in the liver for lengthy periods of time.

13 Curtin, “'The White Man's Grave': Image and Reality, 1780-1850," 104.

14 Webb, Humanity's Burden, 3.

15 A useful policy, as most breeds of mosquitoes feed at night.

16 European naval surgeons employed Galenic medical practices well into the nineteenth century. See Christopher Lloyd and Jack Coulter, Medicine and the Navy 1200-1900 (London, 1961) and Owsei Temkin, Galenism: Rise and Decline of a Medical Philosophy (Ithaca, 1973).

17 Curtin,““The White Man's Grave': Image and Reality, 1780-1850,” 100. 
slavers flying the British flag. ${ }^{18}$ After the Napoleonic War, the British government enlarged its jurisdiction with a series of bilateral agreements with foreign nations that established reciprocal right of search treaties and provided for mixed commissions to adjudicate captured slavers. ${ }^{19}$ Eager to provide the resources necessary to combat the slave trade and thereby secure a prominent peacetime role for the navy, the Admiralty steadily increased the size of the antislavery squadron. By 1844, the Royal Navy maintained a considerable force of twenty-two vessels on the West African station. ${ }^{20}$

British health regulations did little to minimize the risk of tropical disease. Indeed, it seems that the Royal Navy suffered from lack of institutional memory in dealing with fever. In 1805, Scottish explorer Mungo Park led a government expedition up the Niger River that ended in disaster when fever ravaged his European crew. ${ }^{21}$ The posthumous publication of his journal raised public awareness of the dangers of the African climate. Nevertheless, the Admiralty continued to sanction voyages into the interior. In 1825, malaria struck down a British canoe expedition after its members camped in the low-lying region of the Vellar estuary in present-day Nigeria. A journal editor denounced this lack of common sense: "how an old naval surgeon and two experienced naval officers could commit such an imprudence, in such a climate, is to us most surprising, when most dreadful consequences are well known to have almost invariably resulted from such a practice in tropical climates." ${ }^{22}$ A subsequent voyage up the Niger River in 1832 resulted in the death of thirty-nine out of forty-seven European sailors. $^{23}$

The most infamous case of "African Fever" occurred during the 1841 Niger River expedition. ${ }^{24}$ Organized by abolitionist Thomas Fowell Buxton, three government steamers attempted to ascend the Niger River in order to establish a model farm and commence "legitimate trade" in the interior. Accompanying surgeons employed strict regulations to preserve the health of the expedition. They ordered all white personnel to remain below deck during the evenings, and installed elaborate ventilation systems to circulate fresh air. In addition, they selected experienced sailors with healthy physiques

18 These early cruisers operated as detached vessels from other squadrons, as the station only became a permanent West African squadron in 1819. See Christopher Lloyd, The Navy and the Slave Trade, 67.

19 Great Britain signed treaties with Spain (1848), Portugal (1848), the Netherlands (1819), Sweden (1827), Denmark (1835), Venezuela (1840), Uruguay (1843), Mexico (1843), Chile (1843), and Bolivia (1843). See Chronological Table of the Statues Covering the Legislation to the $31^{\text {st }}$ December, 1958 (London, 1959). Significantly, these treaties did not extend to France or the United States. See Lloyd, The Navy and the Slave Trade, 44-50.

20 Lloyd, The Navy and the Slave Trade, 282.

21 Mungo Park, The Journal of a Mission to the Interior of Africa (Philadelphia, 1815).

22 The Quarterly Review XXXIX (January 1829), 145.

23 Lloyd, The Navy and the Slave Trade, 21.

24 For a detailed account of the Niger River Expedition, see Howard Temperley, White Dreams, Black Africa: The Antislavery Expedition to the Niger River 1841-1842 (New Haven, 1991). 
and prior service in tropical climates. ${ }^{25}$ Despite these precautions, the expedition failed after malaria incapacitated the European crews. Before the fever abated, forty-three white sailors died and thirty were invalided out of a total contingent of $145 .{ }^{26}$ As senior officer of the expedition, Captain Henry Dundas Trotter offered little explanation for the high mortality, merely stating "it is a consolatory circumstance to find that the natives of Africa who were taken from Sierra Leone and Liberia did not suffer in the slightest degree from its effects." ${ }^{27}$ Faced with the reality of "the White Man's Grave," the Peel Ministry abandoned the Nigerian settlement and prohibited future government expeditions up the river. As one historian concluded, "the project broke against the hard facts of Africa." ${ }^{28}$

British logistical arrangements also contributed to the African Squadron's high mortality rates. The use of Sierra Leone as the major base of operations placed the squadron in close proximity to the Slave Coast and allowed British cruisers to remain on station for an extended period of time. Moreover, the establishment in 1817 of a Court of Mixed Commission at Sierra Leone ensured that most British prize crews returned there for adjudication. These convenient arrangements also placed squadron personnel in the most insalubrious location in the entire British Empire. Annual mortality among Europeans at Sierra Leone averaged fifty percent, reaching its horrific climax in 1825 when disease caused the death of eighty-six percent of the British garrison. ${ }^{29}$ Disease also took a high toll on the officials assigned to the courts of mixed commissions. Both British and foreign governments experienced continual difficulties keeping these positions filled, as suitable candidates considered the post akin to a death sentence. ${ }^{30}$ Early efforts to employ the offshore island of Fernando Po as an alternative base failed after naval authorities blamed an outbreak of yellow fever on local conditions. ${ }^{31}$ In 1829 , HMS Eden arrived in Fernando Po with nearly fifty cases of yellow fever contracted during a visit to Sierra Leone. The fever quickly spread throughout the squadron, killing 202 sailors and putting an end to plans for a base away from the mainland. ${ }^{32}$ One Royal

25 James Ormiston McWilliam, Medical History of the Expedition to the Niger During the Years 1841-1842 (London, 1843), 5, 16-23. McWilliam reveals that surgeons only applied cinchona bark or quinine as a remedy late in the recovery process (198).

26 Parliamentary Papers (hereafter P.P.), 1843, Vol. XLVIII, 108, 113-115.

27 Ibid., 102. This incident also generated much interest in the United States, particularly from abolitionist and missionary societies and papers. For a sampling of these papers, see: African Repository and Colonial Journal (May 1842); Boston Medical and Surgical Journal, 18 May1842; New York Observer and Chronicle, 12 March 1842; Boston Recorder, March 4, 1842; Episcopal Recorder, 5 February 1842; The Catholic Telegraph, 29 January 1842.

28

29 John Gallagher, "Fowell Buxton and the New African Policy," 58.

Curtin, Disease and Empire, 8, 15.

Leslie Bethell, "The Mixed Commissions for the Suppression of the Transatlantic Slave Trade in the Nineteenth Century," Journal of African HistoryVII, no.1(1966), 87-88.

Robert Brown, "Fernando Po and the Anti-Sierra Leonean Campaign, 1826-1834," International Journal of African Historical Studies 6, no.2 (1973), 261-263.

Alexander Bryson, Report on the Climate and Principle Diseases of the African Station (London, 1847), 142. 
Navy surgeon recalled instructions for sailors at Fernando Po as: "Gang No. 1, to be employed digging graves as usual — Gang No. 2, making coffins until farther (sic) orders." 33

The Royal Navy's aggressive measures against the slave trade placed its personnel in dangerous proximity to the coast and its fevers. Using a combination of shallow-draft brigs and steamers, the British adopted a strategy of patrolling the littoral regions to catch slavers when they were most vulnerable - while loading slave cargoes. Eventually, this policy evolved into the outright destruction of the slave marts and barracoons. In 1840, a young naval officer and abolitionist named Joseph Denman initiated an aggressive blockade of the Gallinas River region (on the border of Sierra Leone and Liberia) and razed several barracoons operated by foreign slave traders. Embodying the most bellicose traits of Palmerstonian gunboat diplomacy, Denman's actions received government approval established the close blockade as the staple of British antislavery policy. ${ }^{34}$ These methods, combined with the development of local logistical arrangements, were effective in combating the slave trade, but at a great price in sailor mortality. Exposed to the debilitating effects of fever, 1,203 sailors of the British African Squadron died between 1825 and 1845. ${ }^{35}$ One American officer rendered an unsparing, although not unsympathetic verdict on the Royal Navy's practices:

All vessels, except those of our own navy, allow their officers to sleep on shore. They expect to be taken sick, but hope that the first attack of fever will season them. Possibly, this is as wise a course as the British officers could adopt; for, unlike ourselves, they are compelled by duty to trust themselves in pestiferous situations, particularly in the ascent of rivers, where there is scarcely a chance of escaping the deadly influence of the atmosphere. $^{36}$

By contrast, the United States government was hesitant to commit naval forces to West Africa prior to the establishment of a permanent squadron in 1842. ${ }^{37}$ American administrators looked to the high mortality rates in the American Colonization Society's settlements in Liberia as a grim reminder of the dangers of African service. Created as a haven for free blacks, the Liberian colony nearly failed due to the endemic problems of malaria. The establishment of an initial settlement at Sherbro Island in 1820 ended in

33 Peter Leonard, The Western Coast of Africa: Journal of an Officer Under Captain Owen (Philadelphia, 1833), 112.

34 Lloyd, The Navy and the Slave Trade, 93-96.

35 Bryson, Report on the Climate and Principle Diseases of the African Station, 177.

36 Horatio Bridges, Journal of an African Cruiser. Nathaniel Hawthorne, ed. (New York, 1853), 139-140.

37 Despite outlawing the slave trade in 1807, the United States displayed little interest in enforcement on the high seas until disputes with Great Britain over the right of search necessitated increased vigilance against slavers flying the American flag. At the same time, the United States Navy maintained standing squadrons throughout the world for the protection of American commerce. These squadrons included (with the year of their creation): Mediterranean (1815), West Indies (1821), Pacific (1821), Brazil (1826), and East India (1840). See Schroeder, Shaping a Maritime Empire, 17, 37-38. 
disaster when fever killed all of the white administrators and many of the black emigrants who lacked native immunity. ${ }^{38}$ Further attempts at colonization netted similar results as malaria claimed 921 lives out of 4472 emigrants. ${ }^{39}$ As it was, American naval personnel were introduced gradually to the perils of Africa's tropical diseases. Beginning in 1820, the Navy Department began dispatching warships from the West Indies station for periodic visits to the Liberian settlements. In 1823, a party from one of these vessels, the USS Cyane, went ashore to assist the colonists of Cape Mesuarado construct a fort to ward off native attacks. Prolonged service ashore resulted in an outbreak of fever that forced the ship's captain to abandon the work and leave the coast. Before the fever abated, forty of his men died. ${ }^{40}$ These experiences did little to persuade Americans to maintain a standing force on the African coast. One critic worried that American sailors were "to be employed a vast distance from home; on a savage coast; in a perilous service; on both sides of the equator; and in a climate which is death to the white race."41

The creation of the United States African Squadron did little to increase contact with the West African coast. An unpopular provision of the Webster-Ashburton Treaty of 1842, the American squadron never received the proper resources to conduct an effective inshore campaign against the slave trade. ${ }^{42}$ The agreement with Great Britain required both navies to maintain a minimum of eighty guns on the station. In an effort to meet these stipulations with as few ships as possible, the Navy Department routinely

38 P.J. Staudenraus, The African Colonization Movement, 1816-1865 (New York, 1961), 59-61. It came as a surprise to many American Colonization Society leaders when they learned that Black Americans born in the United States lacked immunity against malaria. See Antonio McDaniel, Swing Low, Sweet Chariot: The Mortality Cost of Colonizing Liberia in the Nineteenth Century (Chicago, 1995).

39 Antonio McDaniel and Samuel Preston, "Patterns of Mortality by Age and Cause of Death Among Nineteenth Century Immigrants to Liberia" Population Studies 48, no. 1 (March 1994), 105; Tom Schick, "A Quantitative Analysis of Liberian Colonization from 1820-1893 with Special Reference to Mortality," Journal of African History XII (1971), 145-159.

40 The exact circumstances of the Cyane incident remain somewhat unclear. In his report to Secretary of the Navy Samuel Southard, Captain Robert T. Spence neglected to provide the number of deaths. An 1854 account by squadron officer Andrew Foote lists the number of deaths at forty. House Document 93 Vol. I, $18^{\text {th }}$ Congress, $1^{\text {st }}$ Session, 130-134; Andrew Foote, Africa and the American Flag (New York, 1862), 128.

41 Senator Thomas Hart Benton in Congressional Globe, Appendix, 27 $7^{\text {th }}$ Congress, $3^{\text {rd }}$ Session, 9.

42 Though primarily an agreement over the United States-Canadian boundary, the WebsterAshburton Treaty also addressed Anglo-American tensions over the slave trade and the right of search. The agreement required both navies to maintain naval forces for the effective policing of the slave trade. Southern senators rallied against this provision, and invoked fears of malaria, explaining "this waste of men - this wear and tear of life and constitutionshould stand for something in a Christian land, and in this age of roaming philanthropy; unless, indeed, in excess of love for the blacks, it is deemed meritorious to destroy the whites." Congressional Globe, Appendix, 27 $7^{\text {th }}$ Congress, $3^{\text {rd }}$ Session, 9. For a detailed analysis of the Webster-Ashburton Treaty, see Howard Jones, To the Webster-Ashburton Treaty: A Study in Anglo-American Relations, 1783-1843 (Chapel Hill, 1977). 
dispatched larger sloops and frigates whose slow speeds and deep draughts limited their effectiveness in antislavery patrol. ${ }^{43}$ The assignment of these vessels prevented the Americans from instituting an inshore blockade similar to that maintained by the British squadron. Officers found that "the frigate is too large for a cruiser to chase small slavers in shore, and the coast being without harbors make it necessary to anchor at inconvenient distance from the land." ${ }^{44}$ The American squadron also lacked a base close to their cruising station. In contrast to the Royal Navy's use of Sierra Leone to maintain an immediate presence, American cruisers operated out of the distant Cape Verdes Islands - over 1,000 miles from West Africa's major slave trading area. This constraint greatly hampered the ability of American cruisers to patrol the coast, with one commander lamenting "our depots of provisions are so distant from the present slave stations that by the time our small vessels reach them their stores are much exhausted, and we are obliged to return." ${ }^{45}$ These limitations told against the squadron's efforts to suppress the slave trade $^{46}$ Yet the very nature of what one historian has termed "desultory cruising" shielded American sailors from the worst conditions of the coast. ${ }^{47}$

The American squadron also profited from comprehensive medical policies established by its first commander, Commodore Matthew C. Perry. ${ }^{48}$ No stranger to tropical diseases, Perry drew upon prior service in Africa and the West Indies to develop preventive measures aimed at ensuring proper sanitation and limiting contact with the coast. ${ }^{49} \mathrm{He}$ issued heavy cloth and wool jackets to protect sailors from the "miasmic airs" thought to contain deadly fever. Despite their incredible discomfort, these unpopular jackets inadvertently protected sailors from mosquito bites. Perry also established restrictions on American excursions ashore. He ordered his captains to "have as little communication with the shore as the nature of your service will allow," and insisted that no American sailor spend a night onshore. ${ }^{50}$ Moreover, he adopted the

43 Several historians posit that the Navy Department placed additional guns on board their vessels in order to reach the minimum requirements of the Webster-Ashburton Treaty. See Pfautz, "The African Squadron of the United States Navy 1843-1861"; Donald Canney, Africa Squadron: The U.S. Navy and the Slave Trade 1842-1861 (Washington, 2006); and Booth, "The United States African Squadron 1843-1861," 77-117.

George Read to George Bancroft, 18 September 1846, Letters Received by Secretary of Navy from Commanding Officers of Squadrons, African Squadron 1843-1861 (hereafter "Letters") reel 3.

45 Charles Skinner to George Bancroft, September 11, 1846, Letters, reel 2.

46 During its operational history from 1842-1861, the United States Navy's African Squadron captured a mere twenty-five slave ships, many without human cargoes. By comparison, Britain's Royal Navy seized ninety-one slaves in the year 1848 alone. Booth, "The United States African Squadron 1843-1861," 116-117; Lloyd, The Navy and the Slave Trade, 276. Pfautz, "The African Squadron of the United States Navy 1843-1861," 22.

48 Perry commanded the African Squadron from 1843 to 1845.

49 Perry served as a lieutenant on the Cyane in 1820 while it assisted in the creation of the Liberian colony at Sherbro Island. In addition, his elder brother - famed American naval officer Oliver Hazard Perry - died from yellow fever on the island of Trinidad in 1819. 
longstanding British policy of employing native Kroomen onboard American ships. This tribe of experienced sailors from Liberia had a native immunity to many forms of fever, and they performed boat service and necessary labor ashore "which the constitution of the white man is incapable of bearing." ${ }^{\text {1 }}$ Most importantly, Perry resisted Navy Department efforts to establish a supply depot on the African coast. Responding to Secretary of the Navy David Henshaw's inquiry, Perry insisted "there is no part of the West Coast of Africa ... where the annual mortality of unacclimated white persons living on shore would not be in the present uncleared state of the country from $30-50 \% .{ }^{.52}$

Perry's instructions did much to minimize sailor mortality and improve the image of the African station. By the end of his tenure as commander of the squadron, annual mortality from disease was less than one percent. ${ }^{53}$ Perry attributed these positive results to strict discipline and the prohibition of shore leave. As he pointed out, his flagship, the frigate Macedonian, would finish its commission without "loss of life by the African fever ... such a result will be a strong argument against the prevailing opinion that the climate of Western Africa is pestilential in the extreme and that no care or precaution can guard against its insidious entrance on board ship." ${ }^{54}$ Other participants extolled the good health of the American squadron. In his 1844 annual address, Secretary of the Navy John Young Mason lauded Perry's accomplishments, noting that "the deleterious influence of the climate is only felt by those on shore." ${ }^{, 55}$ A group of officers from the USS Porpoise observed that "with simple precautions, the health of this station is as good as that of any other." ${ }^{96}$ One officer, with an obvious temperance agenda, explained:

In my own vessel - the 'Perry,' - we were cruising for two years, much of the time exposed in boats - frequently absent from the vessel days and nights; boarded seventy vessels, and captured two or three slavers, yet not a single death occurred among the officers and crew. The only sanitary measures adopted, were, not to be on shore during the night and issuing no grog rations during the cruise. ${ }^{57}$

Low mortality and personal testimony did much to negate Perry's own earlier statement that "the Almighty has interdicted this part of Africa to the white race." ${ }^{, 58}$ As one abolitionist editor sardonically concluded, "the failure of the squadrons of the United States and England to abolish the slave trade cannot be imputed to the unhealthiness of

Archives, M206 (hereafter, "Perry Letterbooks"). Perry's initial instructions were continued as standing orders throughout the squadron's existence. See Appendix A.

Matthew Perry to Abel Upshur, 13 April 13 1843, Perry Letterbooks.

Matthew Perry To David Henshaw, 17 May 1844, Letters, reel 1.

The New American State Papers: Naval Affairs Vol. II, K. Jack Bauer, ed. (Delaware, 1981), 213-214.

Canney, Africa Squadron, 67.

Senate Document 395, $27^{\text {th }}$ Congress, $2^{\text {nd }}$ Session, Vol. I., 371.

Bridges, Journal of an African Cruiser, 13.

A. H. Foote, The African Squadron, Ashburton Treaty, Consular Sea Letters (Philadelphia, 1855), 7. For an account of Foote's African service, see Spencer C. Tucker, Andrew Foote: Civil War Admiral on Western Waters (Annapolis, 2000), 52-71.

Matthew Perry to David Henshaw, 4 January 1844, Letters, reel 1. 
the coast as a cruising ground . . . this surely is not an alarming mortality." ${ }^{, 59}$

Unfortunately, not all American officers observed Perry's instructions to avoid sleeping on shore. Only weeks before Secretary Mason had boasted of the African Squadron's good health, an outbreak of fever incapacitated the crew of the USS Preble. The vessel's captain, Commander Thomas Freelon, landed an armed contingent to defend the Portuguese colonists of Bissau against native attacks. During their extended time ashore, over half of the crew came down with fever, and nineteen died. ${ }^{60}$ A furious Perry castigated Freelon for disregarding health regulations by remaining on land. He informed the Navy Department "I fear in regards to the Preble that the precautions enjoined by my instructions to preserve health in the Squadron have not been rigidly adhered to. On this point however I shall make the necessary investigation."61 A subsequent preliminary medical review failed to reach a conclusion after bitter acrimony erupted between Freelon and Surgeon S. Wilson Kellogg. Perry informed the secretary of the navy of this difference of opinion, but confidentially added: "my own observation and inquiries have satisfied me that there has not been that careful observance onboard that ship of the rigid sanatory (sic) regulations established by me, as there should have been, and which have hitherto protected the crew of all the vessels of the original Squadron from serious sickness." $" 62$

Privately, he informed Freelon that only the lack of officers present on the station prevented a proper investigation. ${ }^{63}$

Lesser cases of fever also originated from sailors camping along the littoral. In 1844, an American officer named Horatio Bridges suffered a minor attack of malaria after spending the night ashore at St. Anne de Chaves. Bridges quickly recovered, and even questioned the connection between fevers and the coastal regions. Nevertheless, he admitted that "the fever of the country, where all due precautions have been used, will be much lighter on board, than on shore." 64 Another group of officers reported "a single case of fever on board; and, in that instance, the patient was a man who ran away, and spent a night ashore."65 These occurrences remained the exception, and American policies stood in stark contrast to those of the Royal Navy. As one American naval surgeon explained, "by strict enforcement of sanatory (sic) regulations, our cruisers upon the coast of Africa have suffered little compared with those of other nations, whose operations subject them more to deleterious influences." 66

By the mid-1840s, the Royal Navy increasingly adopted preventative measures

59 The African Repository (April 1850).

60 Samuel Elliot Morison, Old Bruin: Commodore Matthew C. Perry (Boston, 1967), 176.

61 Matthew Perry to John Y. Mason, 2 December 1844., Perry Letterbooks.

62 Matthew Perry to John Y. Mason, 23 January 1845, Perry Letterbooks.

63 Matthew Perry to Thomas Freelon, 8 February 1845, Perry Letterbooks. Letter marked as "never sent" as contents were verbally communicated to Freelon.

64 Bridges, Journal of an African Cruiser, 155.

65 Ibid., 13.

66 New American State Papers: Naval Affairs Vol. II, 402-403. 
similar to those used by the American squadron. In 1847, Dr. Alexander Bryson published an extensive study on the effects of tropical disease on the British antislavery squadron. Bryson reported that prolonged visits ashore caused the majority of feverrelated fatalities. He identified Sierra Leone as the most dangerous location among the navy's ports of call. According to Bryson, lack of discipline among prize crews led to bouts of drunkenness and unwarranted exposure, with outbreak of fever nearly universal after two weeks. ${ }^{67} \mathrm{He}$ recognized the need to retain Sierra Leone as a base of operations, but advocated strict regulations that prohibited shore leave for prize crews. As an alternative, he suggested Ascension Island, with its temperate climate, as the permanent rest camp for sailors. Furthermore, he cautioned naval officers to avoid the West African coast when possible, noting "it is obvious that the nearer boats approach the shore, the greater the risk of contracting disease; and this again is much increased by landing, and still more by sleeping on shore." ${ }^{68}$

Bryson's advice coincided with a general shift in the operational deployment of the British West African Squadron. In 1847, new squadron commander, Commodore Charles Hotham, abandoned his predecessor's aggressive policies in favor of offshore patrols. His actions were guided by a concerted effort to mollify free trade radicals and avoid diplomatic tensions on the African coast. ${ }^{69}$ Nonetheless, concerns about malaria played a significant role in shaping this new course in British naval policy. Hotham maintained that an inshore blockade led to "mental despondency" which adversely affected the men's health. ${ }^{70} \mathrm{He}$ also opposed river cruises, and insisted upon the need for greater discipline as a means of disease prevention. He assured his superiors that "every attention will be paid to the health of those serving under my command, and that it will always be my study to check boat service and avoid other known sources of disease."71 These preventative policies garnered praise from the officers and men throughout the squadron. Serving as a lieutenant under Hotham, future first sea lord Astley Cooper Key recalled his commander as being "peculiarly careful about the health of his men, and one, who, being a single man with a good income, does not care about capturing slavers when it is attended with the risking of the men's lives and health up the rivers." ${ }^{.72}$

British officers quickly extolled Bryson's and Hotham's reforms. In 1850, a House of Lords investigative committee released an extensive report that drew on testimony from over thirty squadron officers. Most opposed river cruises and advocated avoiding visits ashore. They related their past experiences with coastal excursions and

67 Bryson, Report on the Climate and Principle Diseases of the African Station, 9.

68 Ibid., 203.

69 Mark Hunter, "The Hero Packs a Punch: Sir Charles Hotham, Liberalism, and West Africa, 1846-1850," Mariner's Mirror 92, no.3 (August, 2006), 282-299.

70 P.P. 1850, Select Committee of House of Lords to Consider Best Means for Final Extinction of African Slave Trade, Vol.IX, 148.

71 Ibid., 388.

72 This quote illuminates another problem in the antislavery squadrons: the lure of prize money that caused many captains to risk their crew's lives in search of personal wealth. See Philip Colomb, Memoirs of Admiral the Right Honble Sir Astley Cooper Key (London, 1898), 98. 
inshore blockades. Captain George Sprigg's experience validated the warnings in the Bryson report. After delivering a contingent of freed slaves to Sierra Leone, remittent fever infected eighty-six of his crewmen, with one death. ${ }^{73}$ Captain John Adams reported a more severe outbreak of fever during an otherwise healthy cruise. Ordered up the Rio Pongos with fifty men, he returned with only four. Later accounting for this high mortality, Adams noted "I have no doubt it was from our going up the river, which, at low water, is a dreadful place." ${ }^{74}$ Other officers embraced the new prevention policies. Captain Edward Harris Butterfield reported the he cruised no closer than five miles from shore, noting that "within a mile or two there are heavy dews at night.", Captain Henry Matson slightly demurred, arguing that "two miles is as good as 20." Nevertheless, he agreed that river work constituted a danger to the sailors' health, and that "sleeping on shore is often fatal." Another captain admitted that he "never had a serious case of sickness in the boats, and scarcely a slight one; but then we avoided all river work." 77 Statistical data documented this positive trend; as death rates diminished the Lords' committee concluded "all the evidence goes to prove that the prevalent impression as to the general unhealthiness of the Cruising Squadron is without foundation."

Though offshore patrols provided a good defense against malaria, developments in quinine production largely accounted for the dramatic improvement in sailor mortality ${ }^{79}$ In 1820 , French chemists experimenting with cinchona bark identified and isolated the quinine alkaloid into a concentrated form. ${ }^{80}$ Subsequent trials in France and the Netherlands pointed to the strength of quinine as an anti-malarial drug. Scientists found that small dosages of quinine surpassed regimens with much larger quantities of cinchona bark in combating the symptoms of fever. The result was an explosion of public fascination throughout Europe and North America as consumers sought to get their hands on this new miracle drug. To meet public demand, pharmaceutical companies began large-scale production of quinine in the mid-1820s, and by the 1840s physicians could prescribe quinine as an affordable alternative to cinchona bark. ${ }^{81}$ European colonies in West Africa became particularly strong markets for quinine products. Private consumption of quinine among colonists steadily increased, so that by 1847 Bryson could record that "there is hardly any part of Western Africa where there are resident Europeans, in whose houses it is not to be found; it is in fact considered to be one of the

P.P. 1850, Select Committee of House of Lords to Consider Best Means for Final Extinction of African Slave Trade, Vol.IX, 256.

Ibid., 283.

Ibid., 233.

Ibid., 207.

Ibid., 288.

Ibid., iii.

For an expert analysis of British naval medicine against Malaria and Yellow Fever, see James Watt, "The Health of Seamen in Anti-Slavery Squadrons," The Mariner's Mirror LXXXVIII, no.1 (February 2002), 69-79.

80 Webb, Humanity's Burden, 102-103.

81 Ibid., 106-107. 
necessities of life, where life is of all things most uncertain." 82

As quinine's reputation grew, British naval officers began experimenting with the new drug as an alternative to traditional remedies. ${ }^{83}$ During the ill-fated 1841 Niger River expedition, Surgeon T.R.H. Thompson conducted a personal experiment with quinine regimens. Thompson administered cinchona bark mixed with wine to the ship's crew, while he took a daily dose of quinine. The results were a strong indication of the powers of quinine; as the rest of the expedition slowly succumbed to fever, Thompson escaped infection. His subsequent report in a prominent British medical journal did much to raise public awareness of the need for quinine use among naval personnel on the African station. ${ }^{84}$ In 1847 the Bryson report noted that "of all the remedies employed in fever . . . there is not any so unequivocally valuable as the disulphate of quinine." 85 Bryson insisted upon its universal application. ${ }^{86}$ These influential endorsements ensured that British naval administrators in the late 1840s began requiring the use of quinine on board all vessels on the African station. ${ }^{87}$ Yet naval surgeons lacked both a clear understanding of its use, and an established policy for its implementation. When used as healing tonic or combined with dangerous procedures such as mercury healing and bloodletting, quinine was not effective.

In 1854, Royal Navy surgeon William Baikie shed important light on the qualities of quinine after completing clinical trials during an expedition up the Niger River. Baikie argued that strong doses of quinine taken in advance of exposure did much to reduce the incidences of malaria, noting that it "not only cures but prevents." $88 \mathrm{He}$ called for the standardization of quinine dosages, and urged individual surgeons to oversee medical discipline. Though failing to associate malaria with mosquitoes, Baikie recognized the delayed incubation period and stressed the need to continue dosage of quinine for two weeks after exposure. ${ }^{89}$ As a measure of success, his recommendations allowed the expedition to return without the loss of a single man from fever. ${ }^{90}$ Further experiments reinforced these lessons, leading Bryson (now director of the Royal Naval Medical Service) to conclude that sailors following a strict preventative regimen of

82 Bryson, Report on the Climate and Principle Diseases of the African Station, 244.

83 The Royal Navy's experimentation with "Jesuit's Bark" (Cinchona Tree) dated back to 1757 when Dr. James Lind suggested its use as a cure against fevers. James Lind, An Essay on the Most Effectual Means of Preserving the Health of Seamen (London, 1762), 56.

84 T.R.H. Thompson, "On the Value of Quinine in African Remittent Fever," Lancet 1 (1846), 244-245.

85 Bryson, Report on the Climate and Principle Diseases of the African Station, 244.

86 Ibid., 244-246.

87 Carlson, African Fever, 45-53; Webb, Humanity's Burden, 107.

88 W. B. Baikie, Narrative of an Exploring Voyage up the Rivers Kwo'ra and Bi'reu (commonly known as the Niger and Toadda) (London, 1856), 452, 453.

89 Watt, "The Health of Seamen in Anti-Slavery Squadrons," 76; Baikie, Narrative of an Exploring Voyage, 452-453.

90 Baikie, Narrative of an Exploring Voyage, 5, 453. 
quinine could expect "exemption from all serious febrile disease." prophylactic, quinine offered British and American commanders a considerable defense against the dangers of the fever.

By the mid-1850s, improvements in the general health of the African station allowed both navies to employ new policies that dramatically improved efforts against the slave trade. Due to the aggressive policies of the Royal Navy, the slave trade gradually moved south of the equator to the area surrounding present-day Angola. This relocation forced both squadrons to consolidate their forces into a close blockade at the wide mouth of the Congo River. ${ }^{92}$ The result was a more concentrated effort against slavers. The Admiralty concentrated the West African and Cape of Good Hope squadrons into a single force, while American officers created a comprehensive system of patrols. ${ }^{93}$ In addition, both squadrons increased their allotment of armed steamers. By 1852, half of the British squadron consisted of steamships, with the remaining vessels fast shallowdraft brigs of William Symond's design. ${ }^{94}$ American officers hoped to match the British in force composition, and reported the merits of using steamers in antislavery patrols. They repeatedly requested the dispatch of steamers, noting "the absolute inefficiency of this squadron, composed as it is entirely of sailing vessels." ${ }^{95}$ Despite longstanding intransigence, the Navy Department in 1859 dispatched four modern steamers to the African station.

The logistical requirements for these new policies forced both British and American authorities to reconsider their prohibitions against coastal depots. The need for coal depots to fuel the growing number of steamers ensured that service requirements overrode fears of tropical disease. The Royal Navy increased its existing depot at Loando, while squadron officers called for the creation of another site at Kabenda. ${ }^{96}$ The American squadron commander took this measure a step further, transferring the entire base of operations south of the equator. Upon arriving on station in 1859, Commodore William Inman formally announced that he was moving all American naval stores in the Cape Verdes Islands to Loando, and requested that all subsequent store ships be rerouted accordingly. ${ }^{97}$ These measures ensured that an Anglo-American flotilla of armed steamers could work in close proximity to the slave stations. But it remained unseen how

91 Statistical Report of the Health of the Royal Navy for the Year 1857 found in P.P. 1859 Vol. XVII 82, 77-86.

92 British and American naval officers often established informal agreements to cooperate with joint cruising.

93 Lloyd, The Navy and the Slave Trade, 180; William Inman to William Armstrong, 24 October 1859, Letters, reel 10.

94 P.P. 1852, Return of Vessels Employed on the Coast of Africa, Vol. XXX, 580. As Surveyor of the Navy, Sir William Symonds oversaw the construction of swift, shallow draught brigs carrying ten guns. These vessels became extremely useful for the maritime policing duties of the Royal Navy.

95 Thomas Conover to Isaac Toucey, 13 October 1857, Letters, reel 9

96 Lloyd, The Navy and the Slave Trade, 123.

97 William Inman to Isaac Toucey, 8 August 1859, Letters, reel 10. 
these new policies would affect the health of sailors on the African station. Perry and Bryson's warnings about the dangers of the coast remained firmly entrenched in the consciousness of naval officers.

Despite the hardships of their new duties, the health of sailors on the African station dramatically improved during the 1850s. Between 1855 and 1861, the average annual British mortality on the African station consistently remained below two percent, with the exception of 1859, when an outbreak killed forty-five sailors on HMS Trident. ${ }^{98}$ This rate stood in marked contrast to earlier periods, during which mortality reached as high as twenty-five percent. ${ }^{99}$ American statistical trends were comparable. In 1858, Surgeon General William Whelan used mortality estimates to demonstrate the squadron's "usual immunity from serious illness and death." 100 He showed that from 1855 to 1857 , American death rates remained less than one percent, and that the African Station had lower annual mortality than the Home, Pacific, Mediterranean and East Indian squadrons. Indeed, in 1855 and 1856 the squadron experienced the lowest death rate in the United States Navy. This overall decline in mortality led to one historian's claim that "monotony, not malaria, nor the hazards of the chase, was the chief cause of casualties suffered in the later period." 101 Certainly this statement was an exaggeration, as fever continued to prey upon the antislavery squadrons. Nevertheless, disease prevention and quinine regimens intermittently or gradually diminished the overall threat of tropical fevers.

The story of disease prevention in the antislavery squadrons shows a learning curve among both naval officers and health officials. Through trial and error, both navies eventually secured good health. British and American naval leaders established effective medical policies that mitigated the worse effects of tropical disease. Early mistakes contributed to a greater awareness of the fever's origins that provided latitude in policy choices. Conditions continued to improve so that by 1859 Admiralty officials felt justified in ordering their officers to avoid all rivers and inlets, but "never to lose sight of the coast, if possible, and to cruise from point to point." ${ }^{102}$ Yet these achievements came at a great loss in both operational efficiency and human lives. Balancing the requirements of the service with the need to avoid exposure to the coast placed conflicting demands upon naval officers, who lacked a sophisticated knowledge of epidemiology or disease prevention. Many deaths inevitably resulted as the antislavery

98 P.P. 1850, Return of Mortality Among Crews of H.M. Ships on Coast of Africa, 1840-1848, Vol. LV; P.P. 1857-1858, Return of Number of H.M. Vessels in Squadrons Engaged in Suppression of the Slave Trade, Vol. LXI, 2; P. P. 1861, Return of Names of Ships Employed in Suppression of the Slave Trade, 1855-1859, Vol. LXIV, 2, 5-8; P. P. 1867, Return of Number of Ships of War Employed on West Coast of Africa for Prevention of the Slave Trade, Vol. LXIV, 2-6.

99 In the year 1829, when there occurred 204 deaths out of 792 total personnel. See Bryson, Report on the Climate and Principle, 177-178.

100 Senate Executive Document 977, $35^{\text {th }}$ Congress, $2^{\text {nd }}$ Session, Vol. IV, 672-675.

101 Lloyd, The Navy and the Slave Trade, 183.

102 P.P. 1865, Select Committee on State of British Settlements on West Coast of Africa, Vol.V, 170. 
squadrons continued to perform their duties in the dangerous climate, leading credence to Master's Mate Lawrence's characterization of Africa as "that baleful, and most deleterious of all regions, that most pestilential bowers from which so few white men return that are induced to visit it - or if they return, they only reappear as phantoms of their former selves." 103

\section{Appendix A}

General Order ${ }^{104}$

Sanitary Regulation for the U.S. Squadron on the Coast of Africa, Jan. 17, 1850

1. No officer or man will be permitted to be on shore, before sunrise or after sunset; or to sleep there at night; this rule to apply not only to the continental coast, but to the Cape Verde Islands.

2. No U.S. vessel will ascend or anchor in any of the African rivers, except upon imperative public service.

3. Boat excursions up rivers, or hunting parties on shore are forbidden.

4. Vessels, when possible, will anchor at a reasonable distance from shore; far enough not to be influenced by the malaria floated off by the land breeze.

5. Convalescents from fever, and other diseases when condemned by medical survey; are to be sent to the United States with the least possible delay.

6. When the general health of a ship's company shall be reported as impaired by cruising upon the southern or Equatorial portion of the coast, the earliest possible opportunity will be given them to recruit by transferring the ship, for a time, to the Canaries or other windward islands of the station.

7. Boat and shore duty, involving exposure to sun and rain, is to be performed, so far as the exigencies of the service will permit, by the KROOMEN employed for that service.

8. All possible protection from like exposure is to be afforded to the ship's company on board; and the proper clothing and diet of the crew, as well as the ventilation and care of the decks, will be made a frequent subject for the inspection and advice of the medical officers.

9. These regulations are to be considered permanent, and each commanding officer of the Squadron, on retiring form the station, will transfer them to his successor.

103 Gilliland, Voyage to a Thousand Cares, 24.

104 The New American State Papers: Naval Affairs Vol. II, 400-401. 


\section{Appendix B}

\begin{tabular}{|c|c|c|c|}
\hline \multicolumn{4}{|c|}{ British Mortality on the African Station 1825-1861 ${ }^{105}$} \\
\hline Year & Total Personnel & Deaths & Deaths Per Hundred \\
\hline 1825 & 663 & 48 & 7.23 \\
\hline 1826 & 1,043 & 63 & 6.04 \\
\hline 1827 & 955 & 44 & 4.60 \\
\hline 1828 & 958 & 84 & 8.76 \\
\hline 1829 & 792 & 204 & 25.75 \\
\hline 1830 & 667 & 76 & 11.39 \\
\hline 1831 & 785 & 25 & 3.18 \\
\hline 1832 & 512 & 21 & 4.10 \\
\hline 1833 & 562 & 22 & 3.91 \\
\hline 1834 & 620 & 26 & 4.19 \\
\hline 1835 & 815 & 22 & 2.69 \\
\hline 1836 & 965 & 20 & 2.07 \\
\hline 1837 & 815 & 109 & 13.37 \\
\hline 1838 & 885 & 118 & 13.33 \\
\hline 1839 & 790 & 60 & 7.59 \\
\hline 1840 & 855 & 35 & 4.09 \\
\hline 1841 & 1,070 & 85 & 7.94 \\
\hline 1842 & 1,330 & 72 & 5.41 \\
\hline 1843 & 1,267 & 27 & 2.13 \\
\hline 1844 & 1,715 & 49 & 2.85 \\
\hline 1845 & 2,540 & 128 & 5.03 \\
\hline 1846 & $\mathrm{n} / \mathrm{a}$ & 98 & $\mathrm{n} / \mathrm{a}$ \\
\hline 1847 & $\mathrm{n} / \mathrm{a}$ & 81 & $\mathrm{n} / \mathrm{a}$ \\
\hline 1848 & $\mathrm{n} / \mathrm{a}$ & 63 & $\mathrm{n} / \mathrm{a}$ \\
\hline $1848-1853$ & $\mathrm{n} / \mathrm{a}$ & $\mathrm{n} / \mathrm{a}$ & $\mathrm{n} / \mathrm{a}$ \\
\hline 1854 & 992 & 10 & 1.00 \\
\hline 1855 & 1,082 & 13 & 1.20 \\
\hline 1856 & 1,222 & 17 & 1.39 \\
\hline 1857 & 1,424 & 31 & 2.17 \\
\hline 1858 & 1,714 & 31 & 1.80 \\
\hline 1859 & 1,129 & 76 & 6.73 \\
\hline 1860 & 2,141 & 34 & 1.58 \\
\hline 1861 & 1,938 & 51 & 2.63 \\
\hline
\end{tabular}

105 A note on statistics: British mortality rates for the African Squadron are notoriously incomplete. In addition, naval and medical authorities contained no apparatus for accounting for the number of sailors dismissed from service as "invalids." See Watts, "The Health of Seamen in the Anti-Slavery Squadron" for a discussion of medical records. For the years 1825-1845, see Bryson, Report on the Climate and Principle Diseases of the African Station, 177-178. For the years 1845-1861, see P.P. 1857-1858, Return of Number of H.M. Vessels in Squadrons Engaged in Suppression of the Slave Trade, Vol. LXI, 2; P.P. 1861, Return of Names of Ships Employed in Suppression of the Slave Trade, 1855-1859, Vol. LXIV, 2, 5-8; P.P. 1867, Return of Number of Ships of War Employed on West Coast of Africa for Prevention of the Slave Trade, Vol. LXIV, 2-6. 


\section{Appendix C}

\begin{tabular}{|c|c|c|c|c|c|}
\hline \multicolumn{6}{|c|}{ American Mortality Rates $\mathbf{1 8 4 5 - 1 8 4 8}{ }^{106}$} \\
\hline Year & $\begin{array}{l}\text { Deaths Per } \\
\text { Hundred }\end{array}$ & & & & \\
\hline 1845 & 0.79 & & & & \\
\hline 1846 & 1.06 & & & & \\
\hline 1847 & 1.10 & & & & \\
\hline 1848 & 0.50 & & & & \\
\hline \multicolumn{6}{|c|}{$\begin{array}{l}\text { Mortality of United States Navy Foreign Stations 1845-1848 } \\
\text { Deaths Per Hundred }\end{array}$} \\
\hline Squadron & 1845 & 1846 & 1847 & 1848 & Average \\
\hline Home/W. Indies & 0.39 & 0.66 & 3.84 & 1.78 & 0.82 \\
\hline Pacific & 0.51 & 0.63 & 1.32 & 0.84 & 0.74 \\
\hline Brazil & 0.39 & 1.72 & 0.93 & 0.68 & 0.71 \\
\hline Mediterranean & 0.87 & $\mathrm{n} / \mathrm{a}$ & 0.44 & 0.45 & 0.53 \\
\hline East India & 1.26 & 4.82 & 6.66 & 0.25 & 0.79 \\
\hline Africa & 0.79 & 1.06 & 1.10 & 0.50 & 0.00 \\
\hline
\end{tabular}

Mortality of United States Navy Foreign Stations 1855-1857 $7^{107}$

Deaths Per Hundred

\begin{tabular}{|l|r|r|r|r|l|}
\hline \multicolumn{1}{|c|}{ Squadron } & \multicolumn{1}{c|}{1855} & \multicolumn{1}{c|}{1856} & 1857 & & \\
\hline Home & 1.73 & 0.42 & 0.45 & & \\
\hline Pacific & 0.51 & 0.62 & 0.47 & & \\
\hline Mediterranean & 1.04 & 1.09 & 0.54 & & \\
\hline Brazil & 0.27 & 0.30 & 0.92 & & \\
\hline East India & 3.39 & 3.90 & 4.29 & & \\
\hline Africa & 0.36 & 0.39 & 0.73 & & \\
\hline
\end{tabular}

106 The New American State Papers: Naval Affairs Vol. II, 213-214.

107 Senate Executive Document Vol.977, $35^{\text {th }}$ Congress, $2^{\text {nd }}$ Session. Vol. IV, 672-675. Note that for the years 1855 and 1856, the Brazilian Squadron amassed a slightly lesser death rate, but the African Squadron had the lowest number of deaths with two sailors each year. 